\title{
Characterizing gene responses to drought stress in fourwing saltbush [Atriplex canescens (Pursh.) Nutt.]
}

\author{
LINDA S. ADAIR, DAVID L. ANDREWS, JOHN CAIRNEY, EDWARD A. FUNK- \\ HOUSER, RONALD J. NEWTON, AND EARL F. ALDON
}

\begin{abstract}
Authors are research associate, graduate student, associate professor, associate professor, professor, and research forester, respectively, of the Department of Biochemistry/Biophysics, Department of Forest Science, The Texas Agricultural Experiment Station, Texas A\&M University System, College Station 77843-2135, and the Rocky Mountain Forest and Range Experiment Station, Albuquerque, New Mexico.
\end{abstract}

\begin{abstract}
New techniques in molecular biology can be used to characterize genes whose expression is induced by drought stress. These techniques can be used to understand responses of range plants to environmental stresses at the biochemical and molecular level. For example, they can be used to characterize genes that respond to drought stress conditions in the native shrub Atriplex canescens (Pursh.) Nutt. Complementary DNA (cDNA) libraries constructed from drought-induced messenger RNA (poly A $^{+}$RNA) were used to characterize genes which are associated with the stress response. A cDNA library from $A$. canescens was prepared. This library from stressed shrubs was differentially screened with radiolabeled cDNA probes from stressed and nonstressed shrubs, and apparent drought-induced clones were identified. This is the first report of molecular characterization of drought responsive genes in fourwing saltbush. The identification of genes specific to responses to drought stress could provide a basis for understanding drought tolerance in this important range species.
\end{abstract}

Key Words: Atriplex canescens, messenger RNA, complementary DNA, library, drought stress, differential screening, vector DNA, probe, homology

New techniques in molecular biology can be used to characterize genes whose expression is induced by drought stress. This technology can be used to characterize genes in a variety of plants, including those that are important to range management. The purpose of this paper is to first, discuss the nature of these techniques and show how they can be used to understand responses of range plants to environmental stresses at the biochemical and molecular level; second, provide information about how these techniques can be used to characterize genes that respond to drought stress conditions in the native rangeland shrub Atriplex canescens; and third, provide more insight as to the opportunities now available for identifying genetic characters which in the future may lead to a better understanding of drought tolerance in this important range species.

Fourwing saltbush [Atriplex canescens (Pursh.) Nutt.] is a facultative-evergreen shrub which is native to western North America, extending from Canada to the Sonoran and Chihuahuan Deserts (Stutz and Sanderson 1979). It has been suggested as a favorable range plant for the intermountain region, New Mexico' and west Texas because of its growth and palatability (Plummer

This research was supported by the TAES Expanded Research Program, the Texas Advanced Technology Program, the USDA, Grant 89-38300-4507, and the USFS, Coop. Agmt. 28-C8-485. TAES Technical Article TA25908. Appreciation is extended to Ms. E. McGee for preparation of this manuscript.

Manuscript accepted 15 Feb. 1991.
1970, Springfield 1970, Blauer et al. 1976, Smit and Jacobs 1978, Shoop et al. 1985). It also has been suggested as a biomass, energy feedstock plant in arid and semiarid regions (Newton and Goodin $1985,1987)$. Annual yields of $7,000 \mathrm{~kg} / \mathrm{ha} /$ year have been reported in Utah (Van Epps et al. 1982, Blauer et al. 1976) and 3,500, 4,500, and 7,500 dry kg/ ha / year have been reported in Texas with annual precipitation of 190,380 , and $470 \mathrm{~mm}$, respectively (Newton and Goodin 1985). Atriplex species have been investigated extensively for revegetating disturbed rangelands (Plummer 1970; Aldon 1978, 1984) and are known for their drought-tolerance qualities (Newton and Goodin 1989a). The root system of $A$. canescens may be very deep (up to 6 or $7 \mathrm{~m}$ ), highly branched, and capable of exploiting moisture from a large volume of soil (Goodin 1984). A. canescens has a high water-use efficiency (Dwyer and Degrams 1970) and seedling transplants have attained $80 \%$ survival (Weisner and Johnson 1977).

The genetic variability of Atriplex canescens has been studied thoroughly (Stutz and Sanderson 1979, Goodin 1984, Dunford 1984). Within the distribution range, most populations are tetraploid, but some are diploid, hexaploid, and dodecaploid. Although the phenotypic plasticity within the species is quite great, most of it appears to be heritable (McArthur et al. 1983). Stutz and Sanderson (1979) suggest that in the rapid, recent spread of the species throughout western North America, polyploidy has played a major role in producing new species which have been effective colonizers. Diploids are found on the harsher sites with coarse sandy soils and sand dune areas, whereas tetraploids seem better adapted to the silty clay flood plains of rivers (Dunford 1984). Ecotypic variation among fourwing saltbush populations has been documented (McArthur et al. 1983, Potter et al. 1986) with ecotypes originating from harsh environments having a wider range of adaptation than those originating from more favorable environments (Van Epps 1975, McArthur et al. 1983, Petersen et al. 1987).

Native-shrub species have evolved mechanisms to withstand temperature stress (Newton and Goodin 1989b) and chronic and acute periods of water deficits (Newton and Goodin 1989a). Herbaceous plants have evolved similar mechanisms and responses to drought stress (Jones et al. 1981) and although many mechanisms of drought tolerance are expressed at the gross, anatomical level (e.g., extensive root system), several have cellular and metabolic components. Plants adapt to drought stress through response mechanisms such as osmotic adjustment (Newton et al. 1986a), reduction in DNA content and enhanced tissue elasticity (CastroJimnez et al. 1989), changes in metabolic pathways with the accumulation of compounds such as proline (Bhaskaran et al. 1985, Newton et al. 1986b), appearance of new proteins (Valluri et 


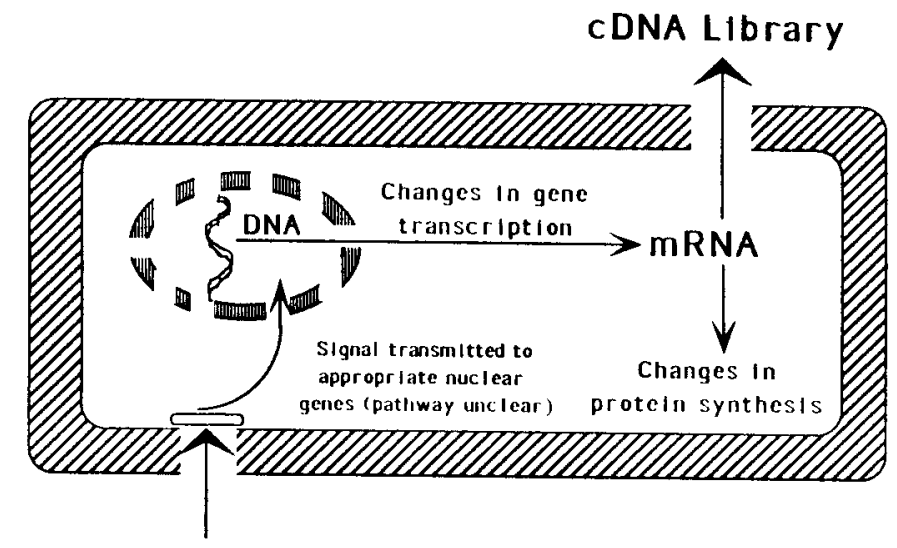

\section{DROUGHT}

\section{STRESS}

Fig. 1. Diagram of a fourwing saltbush cell indicating the response of genes as they are expressed during drought stress and their messages which are subsequently used to synthesize a cDNA library.

al. 1988), and synthesis of the hormone, abscisic acid (Guerrero and Mullet 1986). It is now clear that some of these responses require expression of nuclear genes with changes in transcription (Guerrero and Mullet 1986) and changes in the profile of the translatable poly $\mathrm{A}^{+}$RNA population (Guererro and Mullet 1988).
These induced molecular messengers result in production of proteins.

The synthesis of a number of these proteins can be induced by a variety of stresses, such as wounding, viral infection, heat, cold or the direct application of the hormone abscisic acid (ABA), while production of others is specific to a given environmental condition (Skriver and Mundy 1990). The identity and function of some of these proteins is beginning to be understood in a number of plant systems. For example, conditions, such as heat, which tend to denature nascent polypeptides cause increased production of 'heatshock proteins' involved in correct protein folding (Ellis 1990). Denatured or misfolded proteins which escape the influence of these proteins are targeted for destruction by ubiquitin, a small protein whose levels rise under stress and which works in concert with a variety of enzymes (Hershko 1991). Plants under attack from insects of fungi, or when mechanically damaged to simulate attack, produce a variety of low molecular weight anti-microbial compounds, the phytoalexins. Genes encoding enzymes for phytoalexin biosynthesis are induced by these stresses via specific gene activation (Dixon 1986). Similarly, chitinases and $\beta-1-3$ glucuronidases which degrade fungal cell walls are also produced (Lamb et al. 1989). Genes encoding proteinase inhibitors are rapidly induced in response to attack (Ryan and An 1988). The production of hydroxyproline rich glycoproteins (HPRG's) which strengthen the cell wall is increased in response to drought, heat, or wounding (Showalter and Varner 1989). Genes for a family of calcium bind-
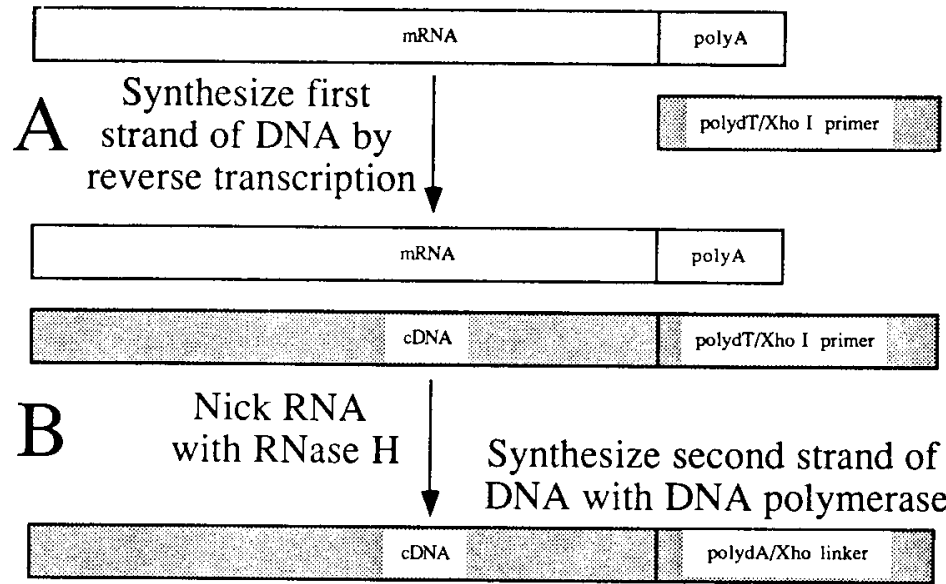

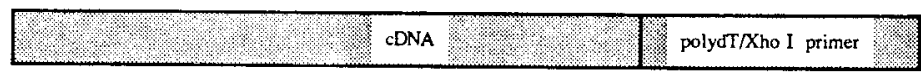

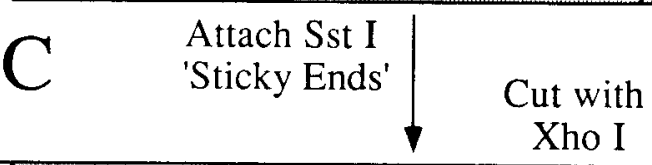

Sst 1 'Sticky End' $J_{1}+4.4 \%$

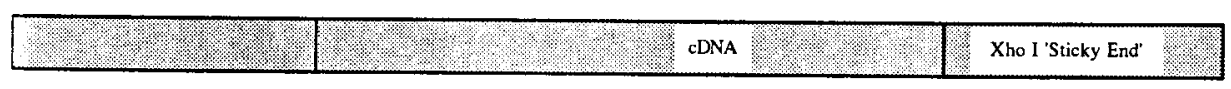

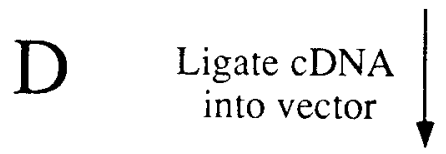

Fig. 2. Flow diagram indicating procedure used to synthesize a cDNA library from messenger RNA isolated from fourwing saltbush.

A. Poly dT/Xho I primer binds to the polyA tail of the mRNA and serves as the priming site for DNA synthesis. Reverse transcriptase is used to produce an RNA/DNA heteroduplex.

B. The enzyme RNaseH introduces cuts into the RNA strand of the heteroduplex. The small RNA fragments thus generated serve as primers for DNA synthesis by $E$. coli DNA polymerase. DNA polymerase synthesizes a complementary DNA strand, and removes RNA as it progresses along the DNA template, producing a double stranded DNA molecule.

C. A small DNA fragment encoding a restriction enzyme site is ligated to the DNA. The purified DNA is cut with Xho I and SSt I. The resulting DNA molecules have "sticky ends".

D. The structure of these ends allow cDNA to be cloned into a vector with compatible ends, in this case $\lambda$ ZAP cut with appropriate enzymes. 
ing proteins in Arabidopsis are induced by a variety of stresses (Braam and Davis 1990). In all the above cases the specific genes are 'activated'by stress and produce more messenger RNA. For the majority of proteins in response to stress, a role in defense and/or repair is yet to be determined. However, physiological changes such as stomatal closure (Bilan et al. 1977), root growth (Meyer and Boyer 1981, Creelman et al. 1990), and stem thickening (Jaffe 1973) in response to stresses are well documented and the proteins responsible for mediating these alterations may be found among the stress-induced proteins.

As described above, many genes are expressed during the drought response through the synthesis of new messenger RNA (mRNA) molecules as shown in Figure 1, and it is possible to obtain DNA clones which represent mRNAs induced by drought stress. To do this, mRNA is first isolated from plant tissues. DNA, copied from a specific template RNA through the action of several enzymes, is called complementary DNA (cDNA) (Gubler and Hoffman 1983). The details of this procedure are shown in Figure 2. Following the synthesis of the second strand, the cDNA is then ligated to another DNA fragment called the vector DNA, which provides for subsequent amplification of the cDNA fragments. The classes of vector DNA's that are usually used are: (1) plasmids: small circular DNA molecules present at high copy number in bacterial cells; and (2) bacteriophage: viruses which infect bacteria, producing hundreds of copies of their own DNA. A 'foreign' cDNA molecule inserted within the vector DNA is replicated as part of the vector DNA during the host's normal biological cycle.

In our experiments, we have employed a derivative of the bacteriophage lambda, $\lambda Z A P$, as our vector (Stratagene, Calif.). Foreign DNA up to 10 kilobases in size can be cloned into sites within the $\lambda D N A$ and is replicated as part of the bacteriophage genome. The cDNA synthesized from poly $\mathrm{A}^{+}$RNA extracted from stressed saltbush tissues was ligated to $\lambda$ arms in vitro (Maniatis et al. 1982). This reaction generates recombinant $\lambda$ DNA molecules, each bearing a different cDNA insert, which together represent all of the mRNA species in the tissues at the time of harvest. Such a representative collection of clones is termed a CDNA library. The $\lambda$ DNA is packaged into its normal phage head in vitro and used to infect the bacterium, Escherichia coli (Maniatis et al. 1982).

Bacteriophage lambda $(\lambda)$ propagates by infecting $E$. coli and uses cell replication machinery to produce 100 to 200 copies of its own genome. The host bacterial cells are lyzed and the released virus particles may then infect surrounding cells. After overnight growth on agar plates, a 'lawn' of bacteria is punctuated by small areas of clearing, called plaques, each containing cell debris, bacteriophage lambda, and naked DNA which resulted from cell lysis. Each plaque stems from a single infection by a single bacteriophage, thus it contains multiple copies of a single (and different) cDNA molecule. By selecting a single plaque from the library, a gene of interest may be isolated. Subsequent propagation of the bacteria with this clone generates large quantities of the desired cDNA molecule.

In the absence of specific information about the genes and proteins activated under drought stress, genes of interest may still be selected by virtue of their changes in expression under this condition by the method of differential screening (Fig. 3). Replicate nylon membrane lifts of plaques are treated so that the DNA is rendered single-stranded and binds to the membrane. Each membrane is then incubated with DNA probes from different sources. The probes are generated from messenger RNA isolated from tissues of nonstressed and stressed shrubs from which 'first-strand' cDNA is synthesized. The cDNA copy is radiolabelled and used to probe the replicate lifts. Homology between the DNA on the membrane and the probe results in pairing of complementary strands attaching the radioactive probe to the membrane at the position where its homologue is situated. When the membrane is exposed to $\mathrm{X}$-ray film, a signal denotes this position. Those plaques which "light up" on both membranes represent genes which are "on" in both nonstressed and stressed tissue. Plaques which "light up" with the stress probe but not the nonstressed probe represent genes which are "on" in stressed and "off" in control shrubs, i.e., drought stress responsive genes. This process, as described in Figure 3, leading to the identification of the responsive "on" gene is called differential screening.

The construction of a cDNA library from drought-stressed tissues and their subsequent differential screening indicates that clones corresponding to poly $\mathrm{A}^{+}$RNAs (mRNAs) induced by stress can be identified. We here report the identification of drought-induced clones from a native-range species which has well-demonstrated drought-tolerance characteristics. The objectives were to: (1) prepare cDNA libraries from drought-stressed and nonstressed fourwing saltbush and (2) probe the libraries to identify, at the molecular level, those clones whose expression is unique to the drought-stress condition. Preliminary reports of this work have appeared (Funkhouser et al. 1989a, Cairney et al. 1990).

\section{Materials and Methods}

\section{Plant Material}

Seeds of Atriplex canescens were provided by investigators at the Rocky Mountain Forest and Range Experiment Station, Albuquerque, N.M. They were sown in flats containing sand fertilized with Hoagland solution (1950) in a greenhouse. The established seedlings were then transplanted to a field site located in Burleson County, Tex.

\section{Differential Screening - Principle}

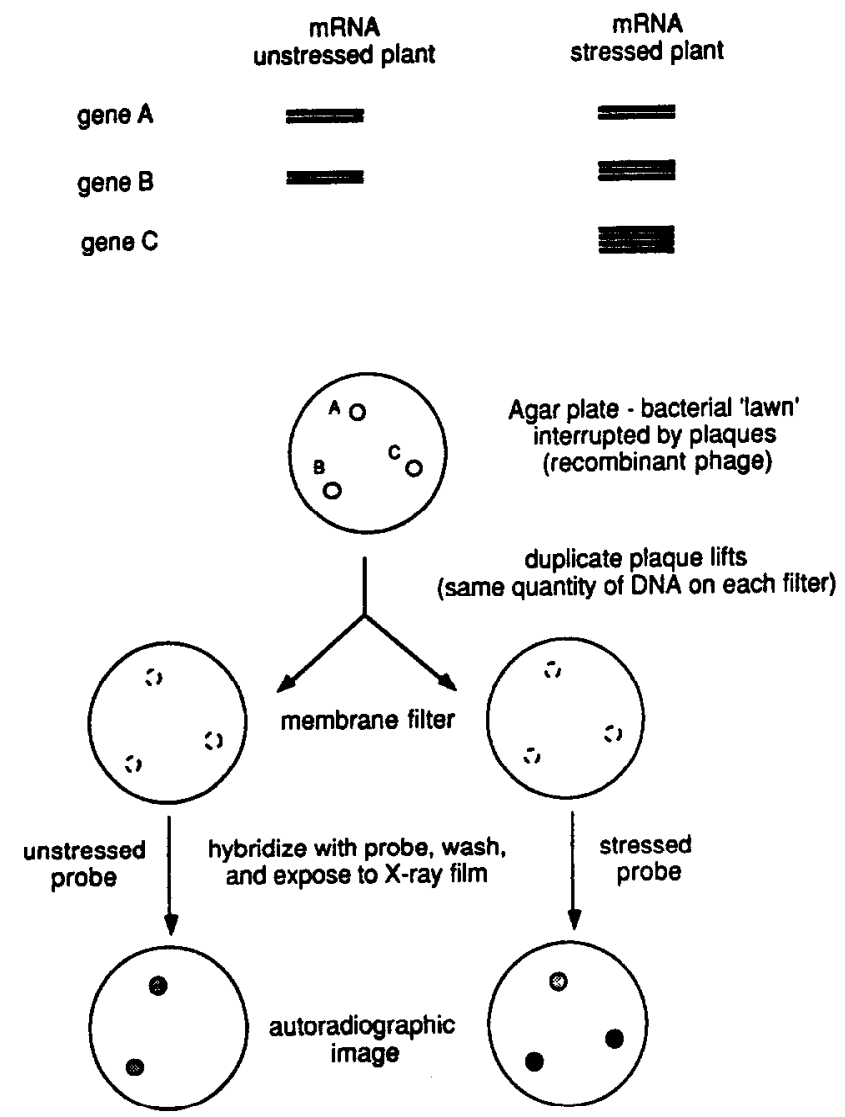

Fig. 3. Synthesis of mRNA under different conditions by 3 hypothetical genes (upper). Recombinant bacteriophage containing the corresponding $\mathrm{cDNA}$ clones hybridizes with a 'stressed' and 'unstressed' probe (lower).

JOURNAL OF RANGE MANAGEMENT 45(5), September 1992 


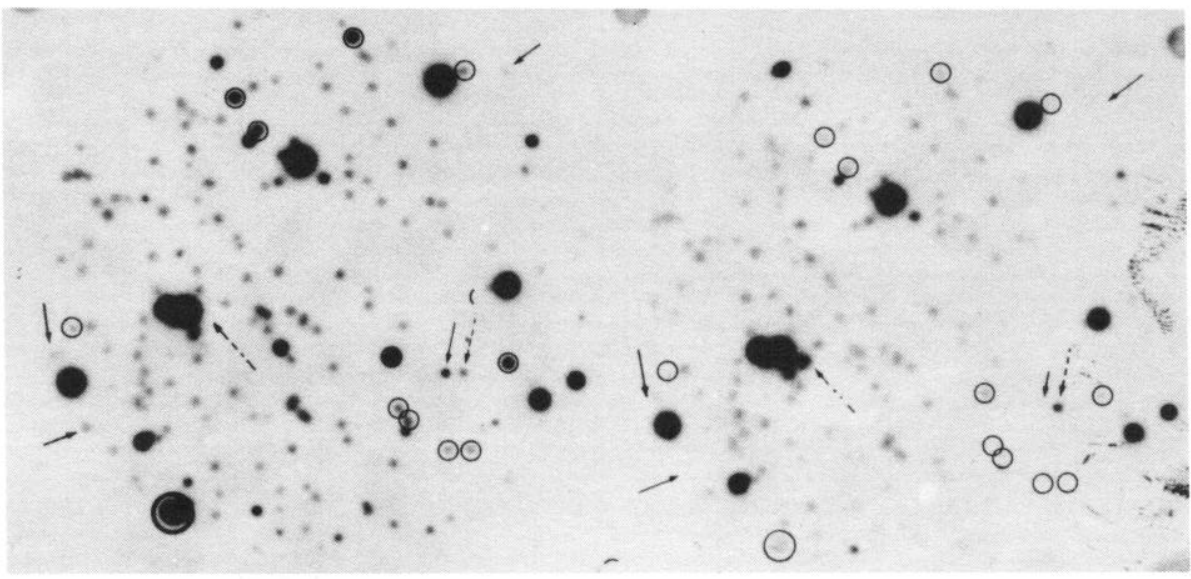

Fig. 4. Primary screen of $\lambda$ ZAP cDNA library of fourwing saltbush using stressed (left) and nonstressed (right) probes.

Clones whose expression is apparently unique to the drought-stress condition are indicated by arrows, those whose expression is increased by drought-stress are indicated with circles. A clone whose expression is decreased by drought-stress is shown by a broken arrow.

\section{Plant Water Status}

Drought stress was induced by withholding irrigation from the soil. As the shrubs experienced the lowered water deficits, plant water potentials $\left(\psi_{\mathrm{w}}\right)$ were determined with a pressure bomb (Scholander et al. 1964) using a branch from each of 3 to 4 shrubs. Branch $\psi_{\mathrm{w}}$ was measured at 4 different times over a period of 1 year.

\section{Isolation of Total RNA}

At the same time that $\psi_{\mathrm{w}}$ was determined, leaves from these same shrubs were collected for RNA extraction. Total RNA was isolated by grinding $10 \mathrm{~g}$ fresh leaves in liquid nitrogen following the phenol-extraction method of Stiekma et al. (1988).

\section{Synthesis and Analysis of cDNA}

The method of synthesis of cDNA was modified from the procedures of D. Andrews and W. Park at TAMU, Department of Biochemistry (pers. comm.). Maintenance of sterile conditions was of prime importance and all solutions were sterilized by autoclaving or filtration according to procedures of Maniatis et al. (1982). For first strand synthesis, cloned MLV (Murine leukemia virus) reverse transcriptase was used rather than the usual AMV (avian myeloblastosis virus) enzyme (Verma 1981). Synthesis of the second strand was a modification (Gubler and Hoffman 1983) of the RNAse H/DNA polymerase I/DNA ligase protocol (Okayama and Berg 1982). This method permits the cDNA's to be directionally cloned, with the Sst I and Xho I 'sticky ends' at the 5' and 3' ends, respectively (Fig. 2).

\section{Preparation of cDNA Library}

Double stranded cDNA was directionally cloned into the commercial bacteriophage $\lambda, \lambda$ ZAP from Stratagene (San Diego, Calif.). The vector was derived from $\lambda \mathrm{GT} 10$ and contains the bluescript plasmid. The $\lambda$ ZAP vector also contains a 454 nt F1 M13 phage intergenic region which allows plasmids to be rescued as single stranded DNA, and subsequently isolated as doubled stranded plasmids (Stratagene, San Diego, Calif.). Synthesis was accomplished with RNA from stressed shrubs.

\section{Differential Screening of cDNA Libraries}

Differential screening of cDNA libraries was used to determine if poly $\mathrm{A}^{+}$RNA levels for some genes change in response to drought stress. To do this, bacteria ( $E$. coli strain XLI) were infected with the recombinant $\lambda \mathrm{ZAP}$ bacteriophage and grown on agar plates to give a density of about 400 plaques per plate. Replicate filters of the stressed cDNA library were obtained according to procedures of Maniatis et al. (1982), as modified by Andrews (Andrews 1990). Nytran filters (Schleicher and Scheull, NH) were placed on cooled plates for 30 seconds and then removed. Replicate lifts were then made by placing a second filter on the plate for 2 minutes. These time periods had been shown previously to give equal quantities of DNA binding to each filter. One duplicate filter was probed with cDNA generated from RNA from stressed $(-0.94$ $\mathrm{MPa}$ ) shrubs and the other probed with cDNA from nonstressed $(-0.41 \mathrm{MPa})$ shrubs. Those plaques displaying stronger hybridization to the stressed probe than those with the nonstressed probe were chosen for rescreening.

\section{Synthesis of Probes}

First strand cDNA was synthesized from poly $\mathrm{A}^{+}$RNA purified from total RNA with hybond-mAP paper (Amersham). Labeled probes were generated by the random-primer method of Feinberg and Vogelstein $(1983,1984)$.

\section{Southern Analysis of Clones}

To release cDNA inserts, plasmids $(0.5 \mu \mathrm{g})$ were cut with Pvull (Promega San Diego, Calif.), subjected to electrophoresis (1\% Agarose) and transferred to a membrane (Nytran) by Southern blotting (Maniatis et al. 1982). The membrane was pre-hybridized with incubation at $42^{\circ} \mathrm{C}$ for 12 hours essentially as described by Maniatis et al. (1982). Approximately $10^{7} \mathrm{cpm}$ of probe synthesized from poly $\mathrm{A}^{+}$RNA from stressed and nonstressed tissue and radiolabelled by the random-primer method was added to the hybridization bag. Hybridization was for 16 hours at $42^{\circ} \mathrm{C}$ followed by washing with $2 \mathrm{XSSC}, 0.5 \% \mathrm{SDS}$ at room temperature for $20 \mathrm{~min}$ (twice); $0.2 \mathrm{XSSC}, 0.5 \% \mathrm{SCS} 55^{\circ} \mathrm{C}$ for $10 \mathrm{~min}$ (once), 1 hour (once). The membrane was exposed to X-ray film for 5 hours. The nonstressed probe was removed from the membrane and was verified by exposing the membrane to X-ray film. Pre-hybridization was repeated for 3 hours before adding $10^{7} \mathrm{cpm}$ of the stressed probe. Hybridization was as described above.

\section{Results and Discussion}

Irrigation was withheld from the shrubs, and branches were 


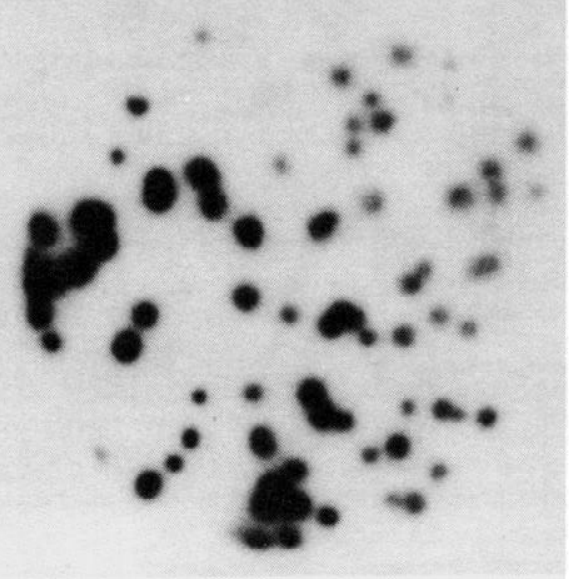

Fig. 5. Secondary screen of putative drought-induced clones using nonstressed (left), and stressed (right) probes.

harvested over several months for both $\psi_{\mathrm{w}}$ measurement and RNA extraction. Branch $\psi_{\mathrm{w}}$ is shown in Table 1. Poly $\mathrm{A}^{+}$RNA (mRNAs) was isolated from leaves of branches removed from shrubs with a mean water potential of $-0.41,-0.62,-0.76$, and $-0.94 \mathrm{MPa}$. Through laborious trial and error, good mRNA preparations from saltbush were finally obtained with procedures modified from others and optimized in our laboratories (Funkhouser et al. 1989a, 1989b; Cairney et al. 1991). The poly $A^{+}$RNA isolated from leaves of the moderately stressed shrubs with a mean branch $\psi_{\mathrm{w}}$ of $-0.94 \mathrm{MPa}$ was used to prepare the complementary DNA (cDNA) library.

In addition to innately expressed genes which also produce tolerance to drought, drought stress may induce changes in gene transcription, either activating formerly quiescent genes and/or elevating or depressing the synthesis of mRNA from specific genes, as shown in Figure 1 and by other workers (Guerrero and Mullet
Table 1. Branch water potential $\left(\psi_{\mathrm{w}}\right)$ of fourwing saltbush collected from a planted field site in central Texas.

\begin{tabular}{lcc}
\hline \hline Harvest Date & $\mathrm{n}$ & $\psi_{\mathrm{w}}$ \\
\hline & & $(\mathrm{MPa}) \pm \mathrm{SD}$ \\
\hline 21 Nov. 1989 & 4 & $-0.41 \pm 0.12$ \\
06 Nov. 1988 & 3 & $0.62 \pm 0.32$ \\
30 Nov. 1988 & 4 & $-0.76 \pm 0.25$ \\
05 Feb. 1988 & 4 & $-0.94 \pm 0.34$ \\
\hline
\end{tabular}

1986, 1988). Therefore, the population of mRNA molecules in stressed $(-0.94 \mathrm{MPa})$ and nonstressed $(-0.41 \mathrm{MPa})$ shrubs should be qualitatively and quantitatively different. This fact can be demonstrated with the process of differential screening.

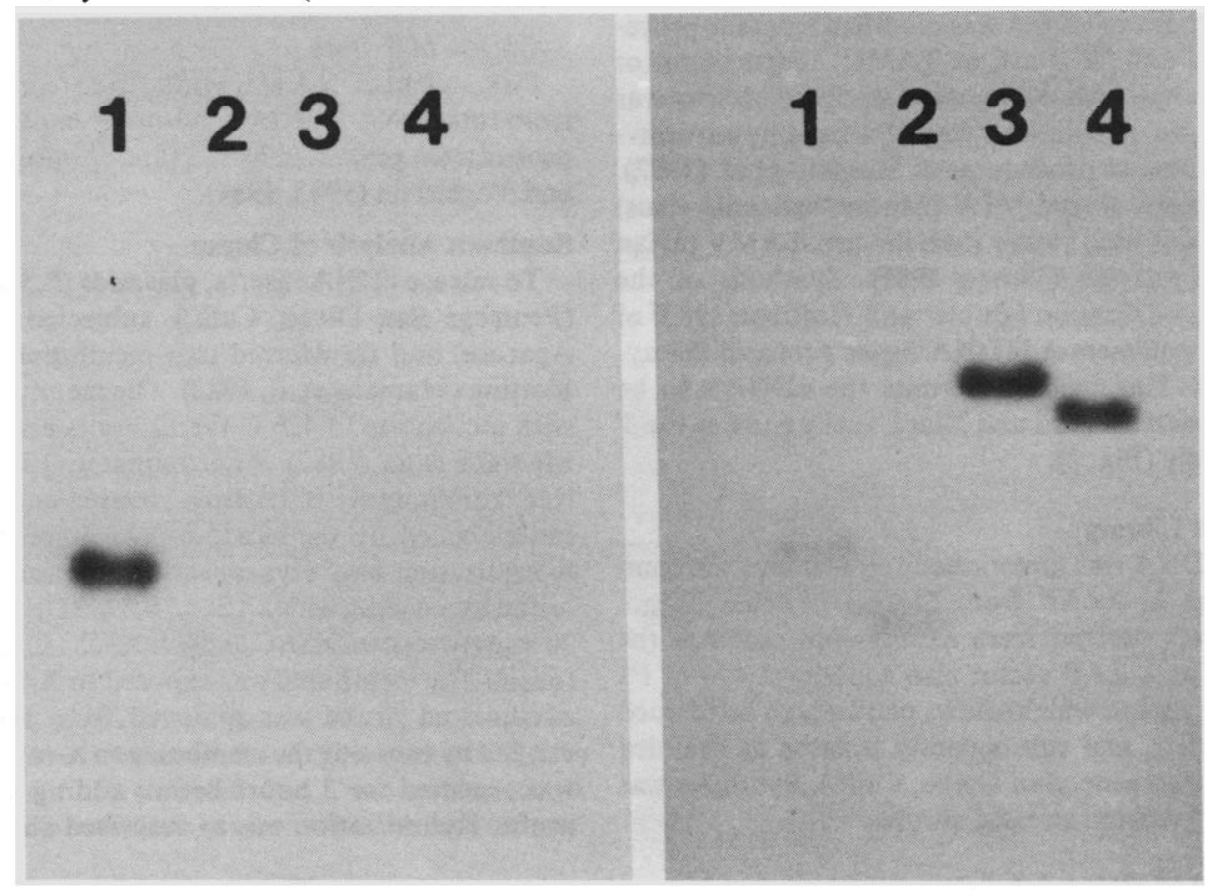

Fig. 6. Southern analysis of clones \#1-3, 8-2, 10-2, and 23-1 with stressed and nonstressed probes from

Left: Hybridization of cDNA inserts with 'nonstressed probe': Lane 1, clone \#1-3; lane 2, clone \# 8-2; lane 3, clone \#10-2; lane 4, clone \#23-1. Right: same membrane with 'stressed probe' 
The cDNA library derived from drought-stressed Atriplex tissues was then differentially screened to identify clones of drought-inducible genes. First, plaques, each derived from a single bacterial host cell in the library and infected with a bacteriophage bearing a unique DNA insert, were produced. Second, replicate nylon membrane lifts of the plaques were then treated with alkali to denature the DNA in situ, separating the strands of the duplex and allowing the DNA to hybridize with incoming homologous molecules.

During differential screening, a radiolabelled cDNA copy of each of the entire mRNA populations of stressed and nonstressed shrubs was made in separate experiments (i.e., 'stressed' and 'nonstressed' probes). When the filters are incubated with the 'stressed' probe, the majority of plaques hybridize with the probe. This is expected since the library was constructed from stressed poly $\mathrm{A}^{+}$ RNA. We thus obtain a radiolabelled 'print' of the position of the plaques on the original agar plate. When a replicate filter is incubated with the 'nonstressed' probe, many plaques hybridize with it and are seen as spots in identical positions on the filters. This result is obtained when the mRNA species corresponding to those plaques are present in both the stressed and the nonstressed plant. It should be stated that a number of genes are expressed at low levels and their mRNAs represent a very small fraction of the mRNA population. The labelled probe derived from these rare mRNAs will not give a strong or even detectable hybridization signal on the short ( 12 hour) expression used here and therefore will not be detected in the screening process.

However, certain plaques do not hybridize with the nonstressed probe, indicating that the corresponding mRNA is absent from the nonstressed population. Therefore, the bacteriophage in the plaque must contain a cDNA copy of a shrub mRNA which is apparently induced under drought stress conditions. A number of drought-induced clones are shown in Figure 4. In addition, a number of clones give signals with both probes, but of different intensities, which is consistent with quantitative changes in their mRNA; i.e., their expression is enhanced by the condition of drought stress. These are shown by circles in Figure 4. A clone regulated in an inverse manner (lower expression under drought stress) is shown by a broken arrow. Because of the limited sensitivity of the screening, the terms 'induced' and 'enhanced' are somewhat artificial: prolonged exposure of a filter can reveal a low level of expression under nonstressed conditions which is not apparent on short exposure. Such low levels of expression are more readily observed in Northern Analysis (Fig. 7).

Plaques which gave strong hybridization signals with the stressed probe, but poor signals with the nonstressed probe (Fig. 5 ), were selected and purified. To confirm that we had picked up the correct plaque and that the different signals were not due to a misplaced filter excluding peripheral plaques or unequal DNA binding to the 2 filters, the screening was repeated using bacteriophage isolated from a single plaque (Fig. 5). In this experiment, all plaques were identical. If we had isolated a single drought-induced clone, all the plaques on the filter should hybridize with the stressed probe, and there should be no hybridization with the nonstressed probe. This is what was observed in most cases (Fig. 5). A number of 'false positives' which hybridized equally well to both probes were identified and eliminated from further consideration.

Fifteen independent clones were identified by this method and the cDNA inserts were isolated in plasmid form from the bacteriophage. Four of the clones (designated 3-1, 8-2, 10-2 and 23-1) had cDNA inserts larger than 1 kilobase (data not shown); these were selected for further study. To confirm that this purified cDNA hybridized to the stressed an nonstressed probes in the expected pattern, these 4 DNA clones were digested with restriction enzyme Pvull, subjected to gel electrophoresis, and transferred to nylon

\section{a $\quad b \quad c \quad d$}

Fig. 7. Northern analysis of RNA from drought-stressed fourwing saltbush shrubs. Four micrograms of poly $\mathbf{A}^{+}$RNA isolated from plants at different water potentials were separated by electrophoresis, blotted onto Nytran membranes (Schleichter \& Schuell, NH) and probed with radioactive cDNA \#8-2. Washing was performed as described for Southern analysis in Materials and Methods section. Water potentials: a; -0.41 MPa, b; -0.62 MPa, c; -0.76 MPa, d; -0.94 Mpa.

membranes. Three of the clones did not hybridize with the nonstressed probe (Fig. 6a), but they did hybridize strongly with the stressed probe (Fig. 6b). One clone (\#1-3) whose pattern of expression was inversed (low expression under stress, high without stress) was also isolated (Fig. 6a). This is the first report of identification of drought-induced DNA clones from fourwing saltbush.

This strategy of differential screening thus permits the identification of clones of genes whose expression is induced or enhanced during drought. These clones were further examined by additional Northern Blot analyses. Poly $\mathrm{A}^{+}$RNA from plants at various degrees of drought stress were separated by electrophoresis on Formaldehyde-agarose gels, transferred to a nylon membrane, and then probed with cDNA inserts isolated from the clones. Figure 7 shows the results for 1 probe, for which we have assigned the number 8-2 for labeling and cataloging purposes. The radioactive probe from this clone binds specifically to its corresponding mRNA. Since the radioactive probe is present in excess, the intensity of signal is determined by the amount of that specific mRNA present in each sample and bound to the filter. For the probe tested, we see that the gene under examination is expressed to a higher degree in shrubs growing at lower water potentials (Fig. 7). This result is consistent with earlier findings (Figs. 4,5,6) and confirms that this cDNA clone for a gene whose expression is induced under conditions of drought stress has been isolated.

Our objective in this study was to examine only field-grown shrubs. Leaves were harvested when different water potentials were reached. Although the sample materials are of different age, the quantity of specific RNA increases with the decreasing water potential of the plant (Fig. 7). Therefore, it is unlikely that the graduated rise in mRNA level observed (Fig. 7) was the result of age difference among the shrubs sampled, but were indeed 
enhanced by drought. It is important to point out that this technique identifies genes whose expression is enhanced under droughtstress. The role of the gene products in metabolism and their contribution to plant survival under adverse conditions is not indicated but must be determined by further experimentation.

Sometimes, homologies among these drought-induced clones from one can species be determined with clones from another species. For example, researchers have identified clones which correspond to poly A $^{+}$RNAs induced in wilted Pisum sativum shoots (Guerrero and Mullet 1988). These stress clones from Pisum could be used to determine homology with the stressed fourwing saltbush species. If this homology between Pisum and Atriplex was demonstrated, it would provide information about the commonality of a particular response among various plant species. If homology is not established between the species, it could indicate that the response observed and/or the clones are perhaps unique to fourwing saltbush. This same approach can be used to determine if unique clones are associated with drought-tolerant and droughtsensitive ecotypes of Atriplex as described by other investigators using other criteria (Van Epps 1975, McArthur et al. 1983, Petersen et al. 1987).

\section{Conclusion}

This report indicates how molecular biology can be used to characterize drought responses of Atriplex at the basic, fundamental level of the gene. This is the first report of molecular characterization of drought-responsive genes in this important rangeland shrub. The results contribute to our understanding of drought responses at the molecular level in a native shrub species which is important to the rehabilitation of disturbed and harsh sites in the semiarid and arid rangelands of the world. This is one of many steps that in the future may provide a basis for understanding mechanisms of tolerance to drought in this valuable range species.

\section{Literature Cited}

Aldon, E.F. 1978. Reclamation of coal-mined land in the S.W. J. Soil Water Conserv. 33:75-79.

Aldon, E.F. 1984. Methods of establishing fourwing saltbush (Atriplex canescens [Pursh] Nutt.) on disturbed sites in the southwest. p. 265-268. In: A.R. Tiedman, E.D. McArthur, H.C. Stutz, R. Stevens and K.L. Johnson, (eds.) Proc. Symp. on the Biology of Atriplex and Related Chenopods. May 2-6, 1983. Provo, Ut. USDA, Forest Serv., Intermtn. Forest and Range Exp. Sta., Ogden, Ut. Gen. Tech. Rep. INT-172.

Andrews, D.L. 1990. Isolation and characterization of differentially expressed cDNA clones from Oryza sativa L., c.v. Lemont. Ph.D. Diss. Texas A\&M Univ. College Station 77843.

Bhaskaran, S., R.H. Smith, and R.J. Newton. 1985. Physiological changes in cultured sorghum cells in response to induced water stress. I. Free proline. Plant Physiol. 79:266-269.

Bilan, M.V., C.T. Hagan, and H.B. Carter. 1977. Stomatal opening, transpiration, and needle moisture in loblolly pine seedlings from two Texas seed sources. Forest Sci. 23:457-462.

Blauer, A.C., A.P. Plummer, E.D. McArthur, R. Stevens, and B.C. Ginuta. 1976. Characteristics and hybridization of important intermountain shrubs. II. Chenopod Family. Intermtn. Forest and Range Exp. Sta. USDA-Forest Serv. RP-INT 177.

Braam, J., and R.W. Davis. Rain-, wind-, and touch-induced expression of calmodulin and calmodulin-related genes in Arabidopsis. Cell 60:357-364.

Cairney, J., L.S. Adair, R.J. Newton, E.F. Aldon, and E.A. Funkhouser. 1990. cDNA cloning of drought-stress related genes from Atriplex canescens (Saltbush). Plant Physiol. 93:106.

Castro-Jimenez, Y., R.J. Newston, H.J. Price, and R.S. Halliwell. 1989. Responses to drought stress in Microseris species differing in nuclear DNA content. Amer. J. Bot. 76:789-795.

Creelman, R.A., H.S. Mason, R.J. Bensen, J.S. Boyer, and J.E. Mullet. 1990. Water deficit and abscisic acid cause differential inhibition of shoot versus root growth in soybean seedlings. Plant Physiol. 92:205-214.

Dixon, R.A. 1986. The phytoalexin response: elicitation, signaling and control of host gene expression. Biol. Rev. 61:239-291.
Dunford, M.P. 1984. Cytotype distribution of Atriplex canescens (Chenopodiaceae) of southern New Mexico and adjacent Texas. The Southwest. Natur. 29:223-228.

Dwyer, D.D., and H.C. DeGarms. 1970. Greenhouse productivity and water-use efficiency of selected desert shrubs and grasses under four soil-moisture levels. N. Mex. State Univ. Agr. Exp. Sta. Bull. 570.

Ellis, J.R. 1990. Molecular chaperones: The plant connection. Science 250:954-958.

Feinbers, A.P., and B. Vogelstein. 1983. A technique for radiolabelling DNA restriction endonuclease fragments to high specific activity. Anal. Bioch. 131:6-11.

Feinbert, A.P., and B. Vogelstein. 1984. Addendum: A technique for radiolabelling DNA restriction endonuclease fragments to high specific activity. Anal. Biochem. 137:266-271.

Funkhouser, E.A., L. Adair, R.J. Newton, and E.A. Aldon. 1989a. Molecular probes for drought stress in native-plant species. Annu. Meet. Soc. Range Manage. Montana State Univ., Bozeman. 21-22 Feb.

Funkhouser, E.A., T.S. Artlip, L.S. Adair, R.J. Newton, and W. Nance. 1989b. Molecular probes for drought-stress in two geographically separated populations of lobolly pine. p. 153-159. In: Proc. of 20th Southern Forest Tree Improvement Conference. Charleston, S.C. 28-29 June.

Goodin, J.R. 1984. Assessment of the potential of halophytes as energy crops for the electric utility industry. Elect. Power Res. Inst. Palo Alto, Calif. AP-3687.

Gubler, U., and B.J.Hofiman. 1983. A simple and very efficient method for generating complementary DNA libraries. Gene. 25:263-270.

Guerrero, F.D., and J.E. Mullet. 1986. Increased abscisic acid biosynthesis during plant dehydration requires transcription. Plant Physiol. 80:588-591.

Guerrero, F.D., and J.E. Mullet. 1988. Reduction of turgor induces rapid changes in leaf translatable RNA. Plant Physiol. 88:401-408.

Hershko, A. 1991. The ubiquitin pathway for protein degradation. Trends Biochem. Sci. 16:265-268.

Hoagland, D.R., and D.I. Arnon. 1950. The water-culture method for growing plants without soil. Calif. Agr. Exp. Sta. Cir. 347.

Jaffe, M.J. 1973. Thigmomorphogenesis: the response of plant growth and development to mechanical stimulation. Planta 114:143-147.

Jones, M.M., N.C. Turner, and C.B. Osmond. 1981. Mechanisms of drought resistance. p. 15-37. In: L.G. Paleg, D. Aspinall (eds.) The physiology and biochemistry of drought resistance in plants. Academic Press, N.Y.

Lamb, C.J., M.A. Lawton, M. Dron, and R.A. Dixon. 1989. Signals and transduction mechanisms for activation of plant defense against microbial attack. Cell 56:215-244.

Maniatas, T., E.F. Fritsch, and J. Sambrook. 1982. Molecular cloning: A laboratory manual. Cold Spring Harbor Laboratory, Cold Spring Harbor, N.Y.

Meyer, R.F., and J.S. Boyer. 1981. Osmoregulation solute distribution and growth in soybean seedlings having low water potential. Planta 151:482489.

McArthur, E.D., R. Stevens, and A.C. Blauer. 1983. Growth performance comparisons among 18 accessions of fourwing saltbush (Atriplex canescens) at two sites in central Utah. J. Range Manage. 36:78-81.

Newton, R.J., and J.R. Goodin. 1985. Unconventional arid land plants as biomass feedstocks for energy. p. 387-397. In. G.E. Wickens, J.R. Goodin and D.V. Field (eds.). Plants for arid lands. George Allen \& Unwin, England.

Newton, R.J., and J.R. Goodin. 1987. Unconventional plants for biomass feedstocks in arid West Texas. p. 1-7. In: J. Tipton (ed.). Occasional Papers of the Chihuauan Desert Research Institute. No. 7.

Newton, R.J., and J.R. Goodin. 1989a. Physiological adaptation of shrubs: moisture stress adaptations. p. 365-383. In: C.M. McKell (ed.). Shrub biology and utilization. Academic Press. N.Y.

Newton, R.J., and J.R. Goodin. 1989b. Physiological adaptation of shrubs: Temperature stress adaptation. p. 385-402. In: C.M. Mckell (ed.). Shrub biology and utilization. Academic Press. N.Y.

Newton, R.J., J. Puryear, S. Bhaskaran, and R.H. Smith. 1986a. Physiological changes in cultured sorghum cells in response to induced water stress. II. Soluble carbohydrates and organic acids. Plant Physiol. $81: 626-629$.

Newton, R.J., S. Sen, and J.D. Puryear. 1986b. Free proline in Pinus taeda L. callus in response to induced drought stress. Tree Physiol. 1:325-332.

Okayama, H.O., and P. Berg. 1982. High efficiency cloning of full length complementary DNA. Mol. Cell. Biol. 2:161-170.

Petersen, J.L., D.N. Ueckert, R.L. Potter, and J.E. Huston. 1987. Ecotypic variation in selected fourwing saltbush populations in Western Texas.J. Range Manage. 40:361-366. 
Plummer, A.P. 1970. Plants for revegetation of roadcuts and other disturbed or eroded areas. USDA-Forest Serv., Intermtn. Range Improv. Notes. 15:1-8.

Potter, R.L., D.N. Ueckert, J.L. Peteraen, and M.L. MeFarland. 1986. Germination of fourwing saltbush seeds: Interaction of temperature, osmotic potential, and pH. J. Range Manage. 39:43-46.

Ryan, C.A., and G. An. 1988. Molecular biology of wound-inducible proteinase inhibitors in plants. Plant Cell Environ. 11:345-349.

Scholander, P.F., H.T. Hammel, and E.A. Hemmingren. 1964. Hydrostatic pressure and osmotic potential in leaves of mangroves and some other plants. Proc. Nat. Acad. Sci. USA 52:1919-1925.

Shoop, M.C., R.C. Clark, W.A. Lay cock, and R.M. Hansen. 1985. Cattle diets on shortgrass ranges with different amounts of fourwing saltbush. J. Range Manage. 38:443-449.

Showalter, A.M., and J.E. Varner. 1989. Plant hydroxyproline-rich glycoproteins. p. 485-520. In: A. Marcus (ed.). The biochemistry of plants. Vol. 15. Molecular biology. Academic Press, San Diego, Calif.

Skriver, K., and J. Mundy. 1990. Gene expression in response to abscisic acid and osmotic stress. Plant Cell. 2:503-512.

Smit, C.J., and G.A. Jacobs. 1978. Skeikundige samestelling van vier Atriplex-spesies. Agroanimalia 10:1-5.
Springfield, H.W. 1970. Germination and establishment of fourwing saltbush in the southwest. USDA Forest Serv. Res. Paper RM-55. Rocky Mtn. Forest and Range Exp. Sta. Fort Collins, Colo.

Stiekma, W.J., F. Heidekamp, W.G. Dirkse, J. van Beckhum, J. deHaar, C. ten Bosch, and J.D. Louwerse. 1988. Molecular cloning and analysis of four potato tuber mRNAs. Plant Mol. Biol. 11:255-269.

Stutz, H.C., and S.C. Sanderson. 1979. The role of polyploidy in the evolution of Atrtplex canescens. p. 615-628. In: J.R. Goodin and D.K. Northington (eds.). Arid Land Plant Resources. Int. Ctr. Arid Semi-arid Land Stud. Texas Tech Univ. Lubbock.

Valluri, J., W.J. Treat, R.J. Newton, and E.J. Soltes. 1988. Water stress proteins induced in pine. Tree Physiol. 4:181-186.

Van Epps, G.A. 1975. Winter injury to fourwing saltbush. J. Range Manage. 28:157-159.

Van Epps, G.A., J.R. Barker, and C.M. McKell. 1982. Energy biomass from large rangeland shrubs of the Intermountain United States. J. Range Manage. 35:22-25.

Verma, I.M. 1981. Reverse transcriptase. p. 87. In: P.D. Boyer (ed.). The enzymes: Nucleic acids. XIV Part A. Academic Press, N.Y.

Weisner, E.L., and W.J. Johnson. 1977. Fourwing saltbush (A. canescens) propagation techniques. J. Range Manage. 30:154-156. 